\title{
Exudative lesions in diabetes mellitus
}

\author{
G. I. HORSFIELD ${ }^{1}$ AND R. LANNIGAN \\ From the Department of Pathology, University of Birmingham
}

SYNOPSIS Exudative lesions and capsular drops have been examined in a renal biopsy series of 25 diabetics and a post-mortem series of 100 consecutive diabetics. Electron microscopy of a capsular drop and an exudative lesion is described. Exudative lesions were found in $48 \%$ of the biopsies and $47 \%$ of the necropsy material. Capsular drops were found in $60 \%$ of the biopsies and $29 \%$ of the necropsy material. No correlation with age, proteinuria, hypertension, or uraemia was noted. The incidence of both types of lesion increased with the known duration of the diabetes.

In addition to the nodular lesion (Kimmelstiel and Wilson, 1936) and the diffuse lesion (Fahr, 1942; Laipply, Eitzen, and Dutra, 1944) the renal glomeruli of diabetics may contain deposits of eosinophilic, hyaline, or granular material having some of the staining reactions of fibrin. These deposits are not specific for diabetes since similar lesions may be found in a variety of renal conditions. Most of the previous descriptions have been from post-mortem material and it has been generally considered that the deposits were terminal. Similar lesions have been found in renal biopsy specimens from diabetics of all ages and severity and the incidence is much higher than might be expected. This communication deals with a series of renal biopsies from 25 diabetics and a series of post-mortem specimens from 100 consecutive cases of diabetes mellitus.

The term 'exudative lesion' was used by Hall (1952) and, although suggesting a pathogenesis which is not yet proven, is in common use. Other authors have incorporated the term 'fibrinoid' in their descriptive titles, e.g., 'fibrinoid crescents' (Spühler and Zollinger, 1943), 'hyaline-fibrinoid lesion' (Koss, 1952), whilst Muirhead, Montgomery, and Booth (1956) described the lesion as the 'acellular hyaline lesion'. Barrie, Askanazy, and Smith (1952) distinguished two types, one affecting the glomerular loops which they called the 'fibrin cap', and one affecting the parietal layer of Bowman's capsule which they called the 'capsular drop'. We have used the term 'exudative lesion' to describe eosinophilic deposits within theglomerular tuft and 'capsulardrop' for the lesion associated with Bowman's capsule.

'Present address: Medical Research Council Unit for Research on the Experimental Pathology of the Skin, Medical School, Birmingham.

Received for publication 20 April 1964.

\section{MATERIALS AND METHODS}

BIOPSY SERIES Twenty-five patients were selected aged between 12 and 54 years and of varying duration of diabetes since diagnosis. The earliest biopsy was carried out three weeks after the onset of acute diabetes and the latest 28 years after diagnosis. The patients had varying severity of diabetes, many had proteinuria, and a few were mildly hypertensive; none were uraemic.

The renal biopsy material, obtained by the method of Muehrcke, Kark, and Pirani (1955), was fixed in formolcorrosive and serial sections taken almost completely through the specimens. These were stained routinely with haematoxylin and eosin, periodic acid Schiff, and Van Gieson's fluid. Several of the biopsies were split and one part was fixed in $1 \%$ buffered osmium tetroxide for 30 to 60 minutes and embedded in methacrylate for electron microscopy. In one of these specimens a capsular drop and an exudative lesion within a hyalinized glomerulus were located and examined on a Siemens series 6 electron microscope.

POST-MORTEM SERIES The post-mortem series consists of specimens from 100 consecutive patients dying from various causes who had suffered from diabetes mellitus. Sections were taken from both kidneys, fixed in $10 \%$ formol saline, and stained routinely with haematoxylin and eosin. Samples were stained with the periodic-acidSchiff reaction, Van Gieson's fluid, Mallory's phosphotungstic acid haematoxylin, Lendrum's acid picroMallory, picro-Mallory V, and Martius Scarlet Blue (Lendrum, Fraser, Slidders, and Henderson, 1962). Control sections of glomeruli containing thrombi were similarly stained. In some post-mortem material fat was demonstrated by the Sudan IV method.

Lesions were recorded as present or absent in any particular case.

\section{RESULTS}

With routine haematoxylin and eosin stains after 
formalin or formal-corrosive sublimate fixation exudative lesions appear as highly eosinophilic masses of varying shape, usually crescentic, round or oval, predominantly situated at the periphery of the glomerular loops (Fig. 1). Frequently they contain globules of fat and in some examples these may form the major part of the lesion (Fig. 2). They may be single or multiple and vary in size. Nuclear material is not present. In most cases the deposit appears to be inside dilated capillary loops and is intimately related to the endothelial side of the capillary basement membrane. In other cases, however, and especially in severely damaged glomeruli, the site of the material is difficult to determine in relation to capillaries (Fig. 3). In a few cases very similar lesions appear to fill the capillary lumen. These can frequently be distinguished from fresh thrombi by their shape and sometimes by their staining reactions.

The capsular drop is an eosinophilic or sometimes slightly basophilic hyaline mass containing variable amounts of fat but no nuclear material. It is usually

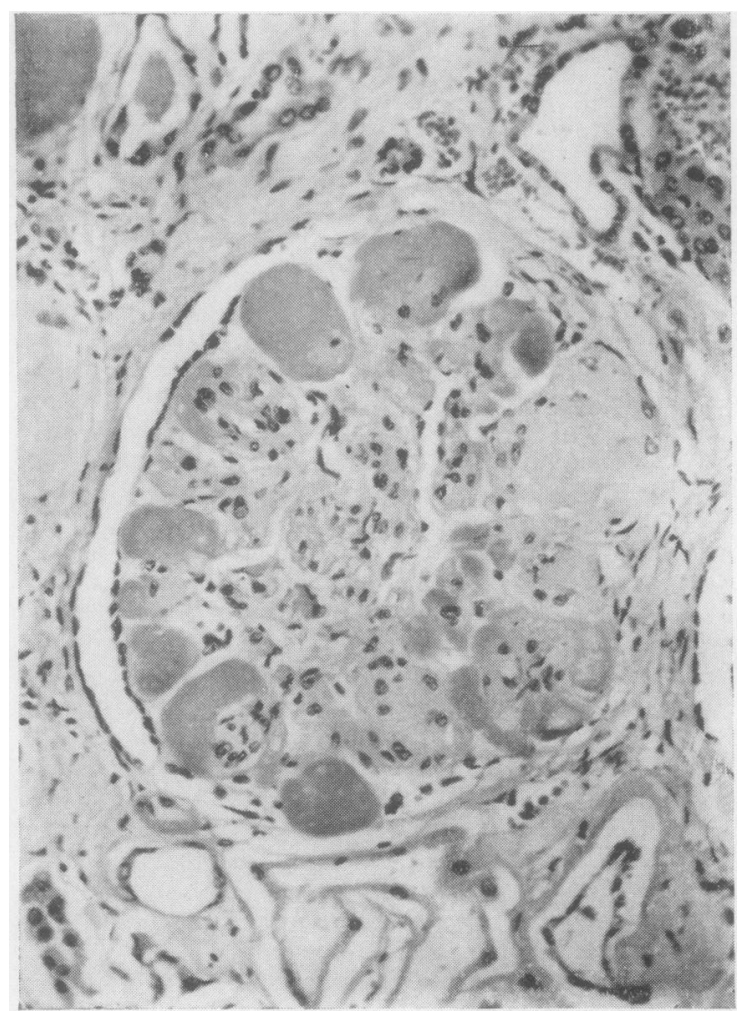

FIG. 1 smaller and less eosinophilic than the exudativ lesion and appears to be attached to the inner surface of Bowman's capsule (Fig. 4), often close t $\overrightarrow{\vec{g}}$ the hilum of the glomerulus. Serial sections readily show that the lesion is not continuous with the 'fibrinoid' or 'hyaline' material frequently found $i \bar{x}$ the afferent and efferent arterioles of the glomerulus in diabetes. In a few cases the epithelial cells of Bowman's capsule contain large amounts of lipiet but no fibrin staining material (Fig. 5). These are usually bigger than the capsular drops and it is doubtful if they represent the same type of lesiogs? although differentiation may be difficult in smati lesions.

STAINING REACTIONS The staining reactions were very variable. All were positive with periodic-acidSchiff stain, but, to varying degrees, stained yello with Van Gieson's fluid, were sometimes orange with Mallory's phosphotungstic acid haematoxyl积 but usually stained blue, and were usually reat with the acid picro-Mallory, picro-Mallory V, an

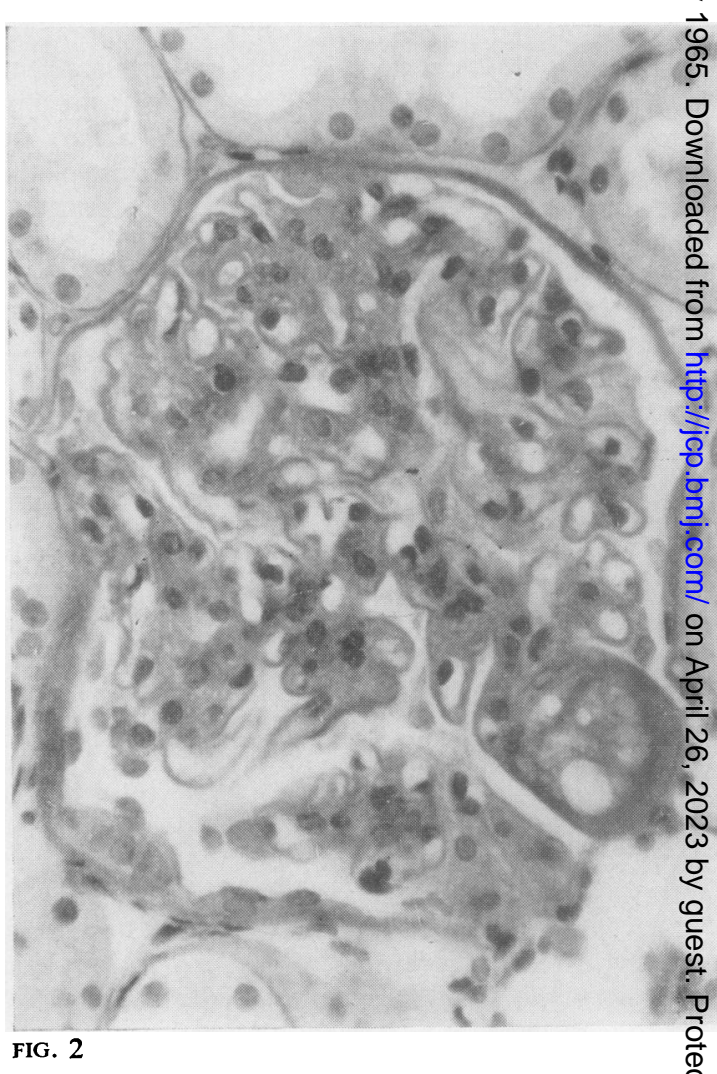

FIG. 1. Several exudative lesions in a severely damaged glomerulus. Some are clearly within dilated capillaries. Haen toxylin and eosin $\times 320$.

FIG. 2. Large exudative lesion. The vacuoles have been shown to contain lipid on frozen section. P.A.S. $\times 370$. 


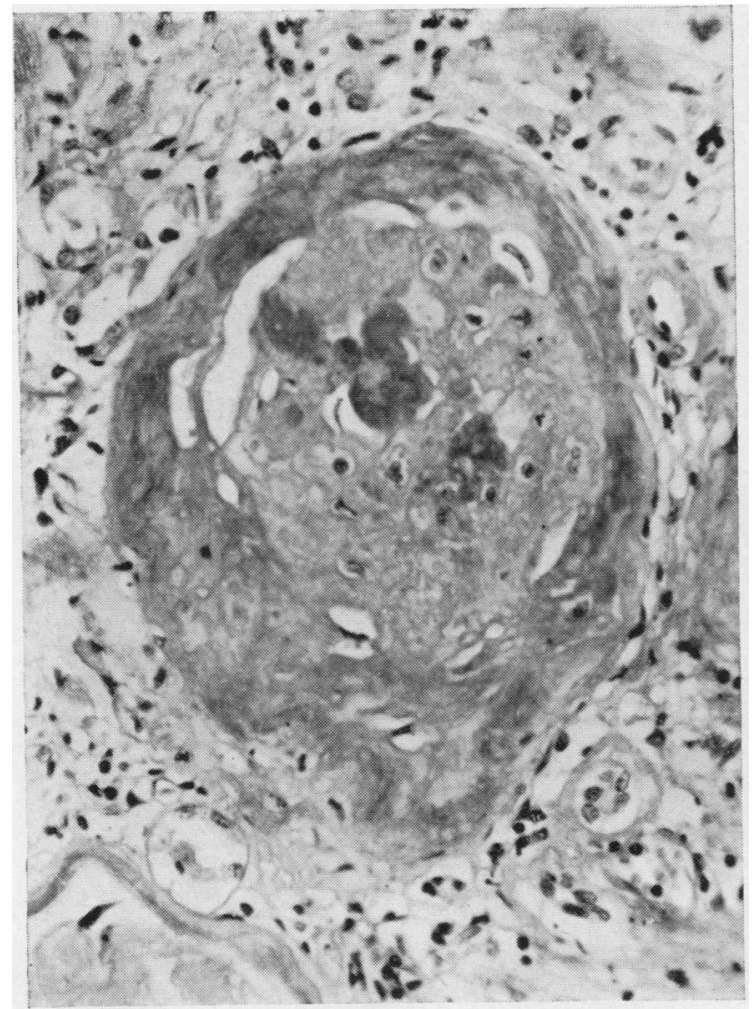

FIG. 3

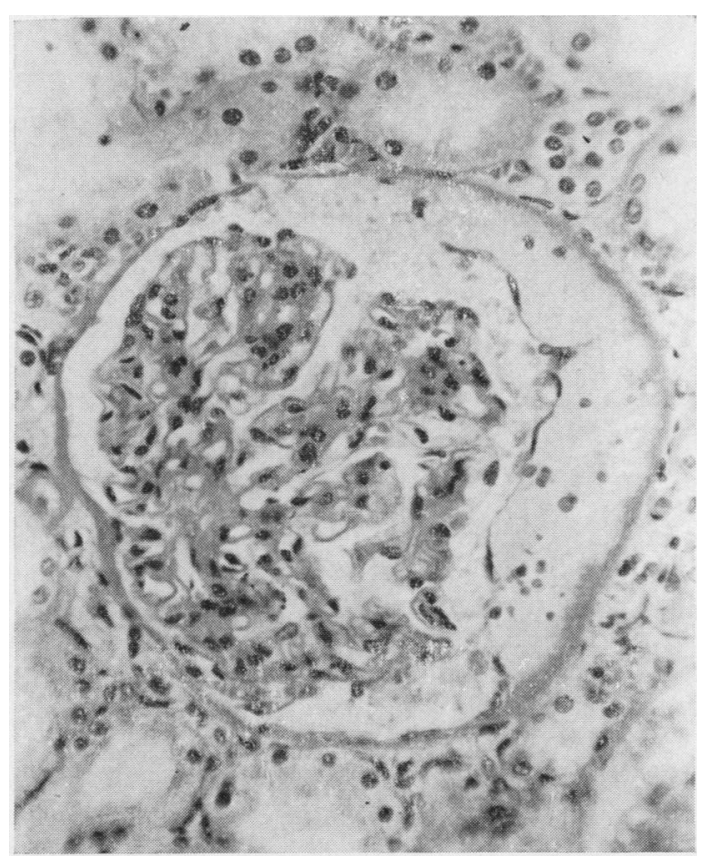

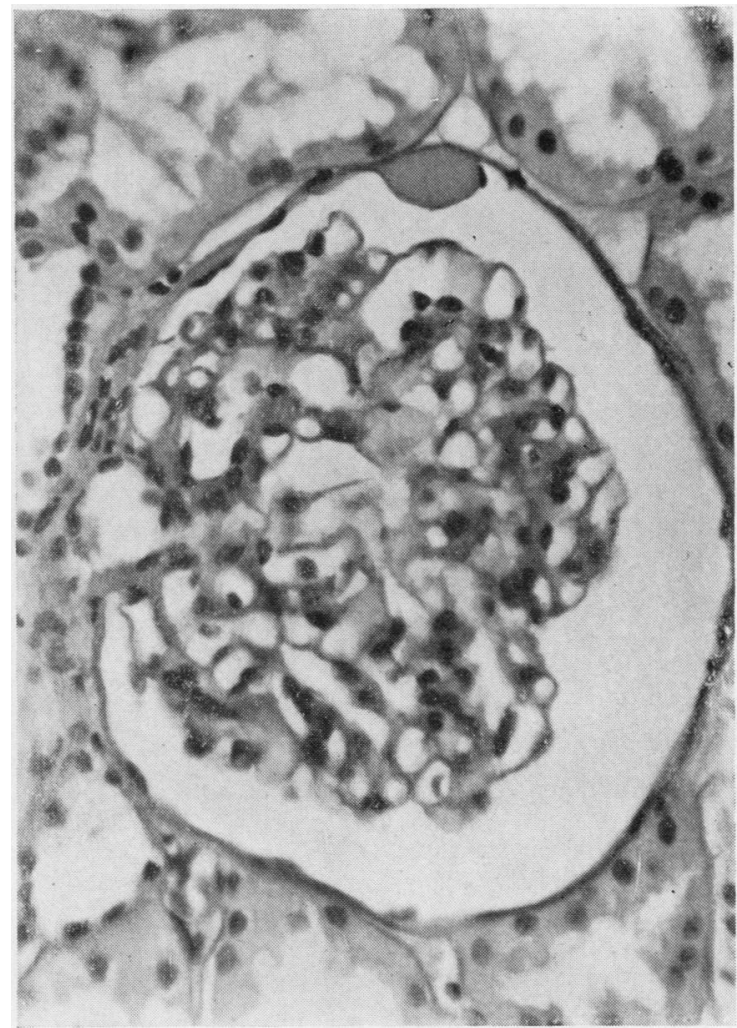

FIG. 4

FIG. 3. Several exudative lesions in an almost completely hyalinized glomerulus. The anatomical site in relation to the capillaries cannot be determined. Picro-Mallory $\times 320$.

FIG. 4. Typical capsular drop. The glomerulus shows an early diffuse lesion. P.A.S. $\times 450$.

FIG. 5. Swollen cells of Bowman's capsule containing lipid. Haematoxylin and eosin $\times 450$.

FIG. 5 


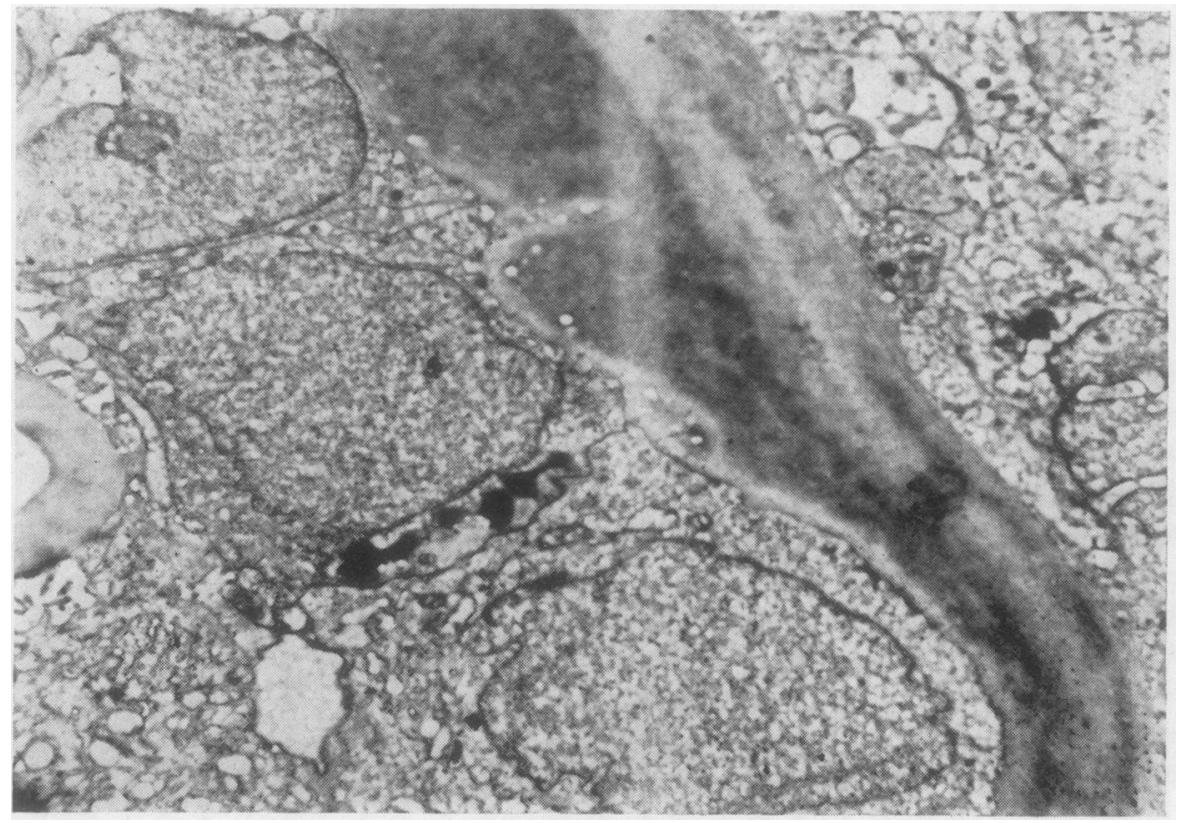

FIG. 6. A small $\overrightarrow{\text { जे }}$ portion of a glomerular capillary is prese on the left and Bowman's capsu灰 obliquely on the right. An amorphous osmiophilic deposit is present on the $\omega$ inner surface of $\overrightarrow{\mathrm{O}}$ Bowman's capsule and appears in $\vec{\infty}$ places to be layered in the capsule. The cells are epitheliab cells and have foor processes. Osmicmethacrylate $\times$ Dे 10,500 .

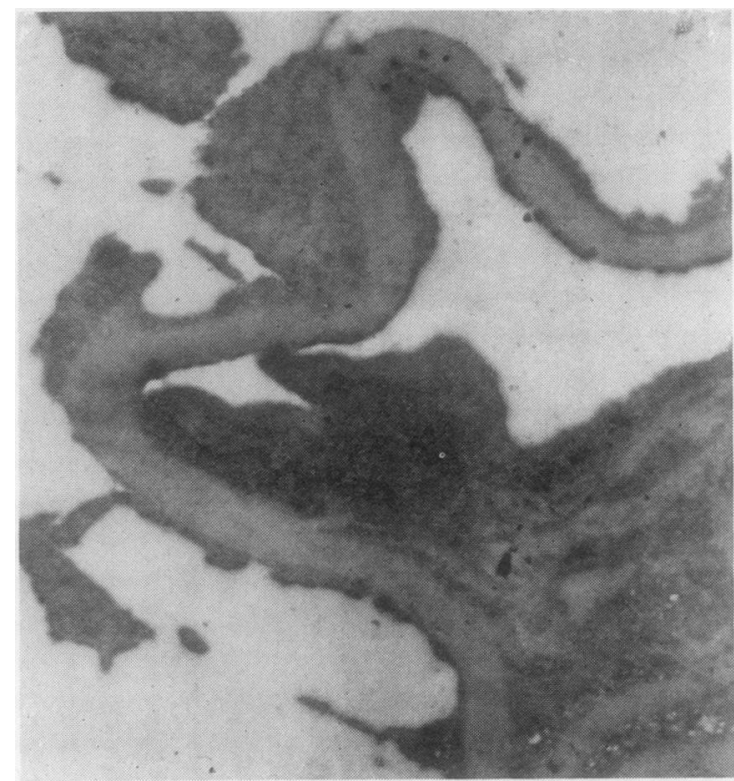

FIG. 7. An open capillary loop at the periphery shows intense osmiophilia of the endothelial cytoplasm and deposits of granular material on the epithelial side of the basement membrane. Similar granular material is found intermingled with basement-membrane-like material within the capillary loop. Osmic-methacrylate $\times 7,500$.
Martius Scarlet Blue. Although the post-mortom material was formalin fixed the control sectims containing thrombi regularly stained as for fibrin

ELECTRON MISCROSCOPY One capsular drop was located in a glomerulus showing a diffuse lesion ạ़d in another glomerulus from the same specimen exudative lesion was noted. The latter glomerusus was almost completely hyalinized.

CAPSULAR DROP The drop consists of demse osmiophilic material situated on the inner surface of Bowman's capsule and separated from Bowmani's space by a narrow homogeneous non-osmioph layer (Fig. 6). At this area the epithelial cells of glomerulus are closely applied to the capsular d and it is difficult to distinguish the cells of Bowman's capsule. At the periphery, however, the lesion is clearly beneath the cells of Bowman's capsule, aftd layers of osmiophilic material similar to that the main capsular drop are found within the capsele itself. The osmiophilic material is amorphous no cytoplasmic components have been recognized.

EXUDATIVE LESION In the exudative lesion within the glomerulus there is a dense osmiophilic depoit which appears to involve all structures except the basement membrane. The glomerulus itself $<$ is 
severely damaged and there are few open loops. In many areas the architecture is destroyed and loops are replaced by masses of material resembling basement membrane. It is impossible in these areas to determine where the lumen of the capillaries has been originally. In the area of the exudative lesion there is an intimate mixture of dense osmiophilic material and the abnormal basement-membranelike material. In one open capillary loop the osmiophilic material is found lining the inner layer of basement membrane in the situation normally occupied by endothelial cytoplasm and in other areas projects into the lumen. On the epithelial side of the basement membrane is a similar deposit occupying the area of the foot process layer and extending into Bowman's space. Within the capillary loop there are strands and masses of basementmembrane-like material surrounded by similar osmiophilic material which projects into the lumen (Fig. 7). No recognizable cytoplasmic components were noted in the region of this osmiophilic material but cytoplasm and nuclei were readily recognized elsewhere. The impression gained from the pattern was that the cytoplasm of endothelial and epithelial cells was involved in the process.

INCIDENCE OF EXUDATIVE LESIONS AND CAPSULAR DROPS The incidence of the histological type of glomerular damage, exudative lesions, and capsular drops is shown in Table $I$ for the biopsy series and Table II for the post-mortem series.

In the post-mortem series it is evident that exudative lesions and capsular drops occur more

\section{TABLE I}

INCIDENCE OF EXUDATIVE LESIONS AND CAPSULAR DROPS IN THE BIOPSY SERIES

\begin{tabular}{lccc}
$\begin{array}{l}\text { Type of Glomerular } \\
\text { Lesion }\end{array}$ & No. of Cases $\begin{array}{l}\text { No. of Cases } \\
\text { with } \\
\text { Exudative } \\
\text { Lesions }\end{array}$ & $\begin{array}{l}\text { No. of Cases } \\
\text { with } \\
\text { Capsular } \\
\text { Drops }\end{array}$ \\
\hline $\begin{array}{l}\text { Nodular } \\
\text { Diffuse alone }\end{array}$ & 5 & 3 & 4 \\
$\begin{array}{l}\text { None visible on light } \\
\text { microscopy }\end{array}$ & 5 & 9 & 10 \\
Total & 25 & 0 & 1 \\
& & $12(48 \%)$ & $15(60 \%)$
\end{tabular}

TABLE II

INCIDENCE OF EXUDATIVE LESIONS AND CAPSULAR DROPS IN THE POST-MORTEM SERIES

\begin{tabular}{lccc}
$\begin{array}{l}\text { Type of Glomerular } \\
\text { Lesion }\end{array}$ & No. of Cases $\begin{array}{l}\text { No. of Cases } \\
\text { with } \\
\text { Exudative } \\
\text { Lesions }\end{array}$ & $\begin{array}{l}\text { No. of Cases } \\
\text { with } \\
\text { Capsular } \\
\text { Drops }\end{array}$ \\
\hline Nodular & 39 & 30 & 18 \\
$\begin{array}{l}\text { Diffuse alone } \\
\begin{array}{l}\text { None visible on light } \\
\text { microscopy } \\
\text { Total }\end{array}\end{array}$ & 27 & 13 & 8 \\
& 100 & 4 & 3 \\
& & 47 & 29
\end{tabular}

frequently when nodular lesions are present. In the biopsy specimens only a few glomeruli are available and the incidence of cases with Kimmelstiel-Wilson lesions is probably underestimated. The biopsy series is also a highly selected group and direct comparison with the post-mortem series is probably not justifiable.

\section{CLINICO-PATHOLOGICAL CORRELATION}

AGE AND DURATION OF DIABETES The relationship between age, known duration of diabetes, and the presence of exudative lesions and capsular drops in the post-mortem series is shown in Tables III and IV.

The majority of the patients were above the age of 50 years and there does not appear to be any direct connexion with age. There is, however, a distinct

\section{TABLE III}

RELATIONSHIP BETWEEN EXUDATIVE LESIONS, KNOWN DURATION OF DIABETES, AND AGE OF PATIENT AT DEATH IN 65 CASES

\begin{tabular}{|c|c|c|c|c|c|c|}
\hline \multirow[t]{2}{*}{ Age (years) } & \multicolumn{5}{|c|}{ Known Duration of Diabetes (years) } & \multirow[t]{2}{*}{ All Groups } \\
\hline & $0-4$ & $5-9$ & $10-14$ & $15-20$ & over 20 & \\
\hline $80-89$ & & $1 / 1$ & & & & $1 / 1$ \\
\hline $70-79$ & $4 / 12$ & $\% 1$ & $3 / 4$ & $1 / 2$ & $8 / 5$ & $\begin{array}{l}11 / 24 \\
(46 \%)\end{array}$ \\
\hline $60-69$ & $2 / 8$ & $2 / 3$ & $2 / 6$ & $1 / 2$ & & $\begin{array}{l}7 / 19 \\
(37 \% \%)\end{array}$ \\
\hline $50-59$ & $2 / 7$ & $1 / 3$ & $0 / 1$ & $1 / 1$ & $1 / 1$ & $\begin{array}{l}8 / 13 \\
(38 \%)\end{array}$ \\
\hline $40-49$ & $\% / 1$ & & $1 / 2$ & & & $1 / 3$ \\
\hline 30-39 & & & $1 / 1$ & $1 / 1$ & & $2 / 2$ \\
\hline $20-29$ & & & & $1 / 1$ & & $1 / 1$ \\
\hline $10-19$ & $1 / 1$ & $0 / 1$ & & & & $1 / 2$ \\
\hline All groups & $\begin{array}{l}\% / 29 \\
(31 \%)\end{array}$ & $\begin{array}{l}4 / 9 \\
(44 \%)\end{array}$ & $\begin{array}{l}7 / 14 \\
(50 \%)\end{array}$ & $\begin{array}{l}5 / 7 \\
(71 \%)\end{array}$ & $\begin{array}{l}4 / 6 \\
(67 \%)\end{array}$ & $\begin{array}{l}29 / 65 \\
(45 \%)\end{array}$ \\
\hline
\end{tabular}

Numerator $=$ number of cases with exudative lesions Denominator $=$ number of cases examined.

\section{TABLE IV}

RELATIONSHIP BETWEEN CAPSULAR DROPS, KNOWN DURATION OF DIABETES AND AGE OF PATIENT AT DEATH IN 65 CASES

\begin{tabular}{|c|c|c|c|c|c|c|}
\hline \multirow[t]{2}{*}{ Age (years) } & \multicolumn{5}{|c|}{ Known Duration of Diabetes (years) } & \multirow[t]{2}{*}{ All Groups } \\
\hline & $0-4$ & $5-9$ & $10-14$ & $15-20$ & over 20 & \\
\hline 80-89 & & $\% / 1$ & & & & $0 / 1$ \\
\hline 70-79 & $\% / 12$ & $\% / 1$ & $2 / 4$ & $1 / 2$ & $2 / 5$ & $\begin{array}{l}8 / 24 \\
(21 \%)\end{array}$ \\
\hline $60-69$ & $3 / 8$ & $2 / 3$ & $2 / 6$ & $1 / 2$ & & $\begin{array}{l}8 / 19 \\
(42 \%)\end{array}$ \\
\hline 50-59 & $\because / 7$ & $0 / 3$ & $0 / 1$ & $1 / 1$ & $1 / 1$ & $\begin{array}{l}2 / 13 \\
(15 \%)\end{array}$ \\
\hline 40-49 & $0 / 1$ & & $1 / 2$ & & & $1 / 3$ \\
\hline 30-39 & & & $1 / 1$ & $0 / 1$ & & $1 / 2$ \\
\hline 20-29 & & & & $1 / 1$ & & $1 / 1$ \\
\hline $10-19$ & $0 / 1$ & $0 / 1$ & & & & $0 / 2$ \\
\hline All groups & $\begin{array}{l}8 / 29 \\
(10 \%)\end{array}$ & $\begin{array}{l}2 / 9 \\
(22 \%)\end{array}$ & $\begin{array}{l}8 / 14 \\
(43 \%)\end{array}$ & $\begin{array}{l}4 / 7 \\
(57 \%)\end{array}$ & $\begin{array}{l}3 / 6 \\
(50 \%)\end{array}$ & $\begin{array}{l}18 / 65 \\
(28 \%)\end{array}$ \\
\hline
\end{tabular}

Numerator $=$ number of cases with capsular drops

Denominator $=$ number of cases examined. 
trend for both exudative lesions and capsular drops to occur more frequently the longer the duration of diabetes. In the biopsy series the numbers in each group are too small to draw any firm conclusion but there is a similar trend.

In the biopsy series the youngest patient with exudative lesions and capsular drops was aged 12 and had been diabetic since infancy. In the postmortem series the youngest patient with both lesions was 28 years old.

HYPERTENSION In the biopsy series 10 patients had a diastolic pressure slightly above $95 \mathrm{~mm}$. of mercury but none were severely hypertensive. Of these 10 patients exudative lesions were found in six and capsular drops in six. Only two cases did not have either lesion. In the 15 normotensives, exudative lesions were found in four and capsular drops in seven. Five cases showed neither exudative lesions nor capsular drops. There is no significant difference between the incidence of either exudative lesions, capsular drops, or both between the hypertensive and normotensive cases.

In the post-mortem series there was also no statistically significant difference between normotensives and hypertensives.

URAEMIA In the biopsy series none of the patients was uraemic and in the post-mortem series no correlation was noted with uraemia.

PROTEINURIA No significant difference in the incidence of exudative lesions or capsular drops was noted in cases with or without proteinuria.

\section{DISCUSSION}

The eosinophilic material in exudative lesions gave staining reactions some of which were positive for fibrin. However, there is no specific chemical stain for fibrin. In the lesions contained within the glomerular tuft we have noted on electron microscopy that the 'fibrinoid' material can be deposited either inside or outside the capillaries. Farquhar, Hopper, and Moon (1959) described a layer of fibrinoid between the endothelium and the basement membrane in an exudative lesion in diabetes. While the common site of the exudative lesion appears to be in this situation, in the most severely damaged glomeruli it is impossible to determine the situation of the deposit. We gained the impression from electron microscopy that the exudative lesion in our case involved endothelial and epithelial cytoplasm and was present inside and outside the basement membrane. This may represent a more advanced type of lesion. In a previous electron microsc study of a similar type of lesion in experimental renal disease the 'fibrinoid' was found in Bowmaु;'s space and extended through the cytoplasmepithelial cells (Lannigan, 1963). In a recent st dy we have noted a similar deposition of eosinoplöbic material in focal glomerulo-nephritis, and, whiple some of this material appeared to be free in Bowman's space, in other areas it occupied the positfon of the foot-process layer and similar material found on the endothelial surface of the membrane.

Recently Lendrum (1963) has claimed that whe exudative lesion is a transudate of fibrin as is the Kimmelstiel-Wilson lesion. He describes The process as 'plasmatic vasculosis'. It appears likely that the exudative lesions are produced by deposits or transudates containing various proteins and lipids but it is also possible that cellular necr@is can contribute to the appearance in some cases. -

The capsular drop has also been explained on the basis of exudation of plasma into Bowman's caps In the lesion we have examined by electron misioscopy there was no evidence of cytoplasmic involwement. The material appears to lie under the cellufar lining and also was found in layers within the capsule itself.

Exudative lesions occurred more frequently Sin damaged glomeruli and the occurrence of exudative lesions and capsular drops in glomeruli whäch appeared normal on light microscopy was unexpected finding. It has, however, been shown fby various authors that alteration to the basement membrane can be noted on electron microscopy epen in very early diabetics where light microscopy thas indicated a normal glomerulus (Sabour, MacDonald, and Robson, 1962; Lannigan, Blainey, and Brewer, 1964).

No correlation was noted with hypertensign, uraemia, and proteinuria. Age by itself had lithle effect. There was, however, a trend for the exudative lesions and capsular drops to increase with the duration of diabetes.

In most published series of renal biopsies diabetes, exudative lesions and capsular drops are fojt listed separately. Taft, Finckh, and Joske (1954) found $25 \%$, Gellman, Pirani, Soothill, Muehr@e, and Kark (1959) $29 \%$, Daysog, Dobson, ard Brennan (1961) $61 \%$, and Hatch, Watt, Kraner, Parrish, and Howe (1961) $28 \%$. In the seriesoof Honey, Pryse-Davies, and Roberts (1962) caps ब्ğar drops were found in $50 \%$. In the present series the incidence is higher than in most but in few of the other series were serial biopsies examined.

Daysog et al. (1961) found exudative lesions?in four of 11 cases of 'prediabetes' and seven of 12 cases of diabetics of less than one year's duration. 
After six years' duration they were present in virtually every specimen.

In one case in our biopsy series exudative lesions were noted in one biopsy and a repeat biopsy two years later showed a similar picture. This would indicate that exudative lesions are probably occurring frequently in diabetic glomeruli throughout the course of the disease and may contribute to the glomerulosclerosis.

We wish to thank Dr. Blainey and Dr. Malins for the clinical information. Some financial assistance was received from the Endowment Fund of the United Birmingham Hospitals.

\section{REFERENCES}

Barrie, H. J., Askanazy, C. L., and Smith, G. W. (1952). Canad. med. Ass. J., 66, 428.

Daysog, A. Jr., Dobson, H. L., and Brennan, J. C. (1961). Ann. intern. Med., 54, 672 .

Fahr, T. (1942). Virchows Arch. path. Anat., 309, 16.
Farquhar, M. G., Hopper, J. Jr., and Moon, H. D. (1959). Amer. J, Path., 35, 721.

Gellman, D. D., Pirani, C. L., Soothill, J. F., Muehrcke, R. C., and Kark, R. M. (1959). Medicine (Baltimore), 38, 321.

Hall, G. F. M. (1952). J. Path. Bact., 64, 103.

Hatch, F. E., Watt, M. F., Kramer, N. C., Parrish, A. E., and Howe, J. S. (1961). Amer. J. Med., 31, 216.

Honey, G. E., Pryse-Davies, J., and Roberts, D. M. (1962). Quart. J. Med., 31, 473.

Kimmelstiel, P., and Wilson, C. (1936). Amer. J. Path., 12, 83.

Koss, L. G. (1952). Arch. Path., 54, 528.

Laipply, T. C., Eitzen, O., and Dutra, F. R. (1944). Arch. intern. Med., $74,354$.

Lannigan, R. (1963). Brit. J. exp. Path., 44, 326. Blainey, J. D., and Brewer, D. B. (1964). J. Path. Bact., 88, 255.

Lendrum, A. C. (1963). Canad. med. Ass. J., 88, 442.

-, Fraser, D. S., Slidders, W., and Henderson, R. (1962). J. clin. Path., 15, 401.

Muehrcke, R. C., Kark, R. M., and Pirani, C. L. (1955). J. Urol. (Baltimore), 74, 267.

Muirhead, E. E., Montgomery, P. O'B., and Booth, E. (1956). Arch. intern. Med., 98, 146.

Sabour, M. S., MacDonald, M. K., and Robson, J. S. (1962). Diabetes, 11, 291.

Spühler, O., and Zollinger, H. U. (1943). Dstch. Arch. klin. Med., 190, 321.

Taft, H. P., Finckh, E. S., and Joske, R. A. (1954). Aust. Ann. Med., 3, 189. 